\title{
Austria's Path to a Climate-Friendly Society and Economy-Contributions of an Environmental Tax Reform
}

\author{
Sebastian Goers ${ }^{1}$, Friedrich Schneider ${ }^{1,2}$ \\ ${ }^{1}$ Department of Energy Economics, Energieinstitut at the Johannes Kepler University, Linz, Austria \\ ${ }^{2}$ Research Institute for Banking and Finance, Johannes Kepler University, Linz, Austria \\ Email: goers@energieinstitut-linz.at
}

How to cite this paper: Goers, S. and Schneider, F. (2019) Austria's Path to a Climate-Friendly Society and Economy-Contributions of an Environmental Tax Reform. Modern Economy, 10, 1369-1384. https://doi.org/10.4236/me.2019.105092

Received: April 16, 2019

Accepted: May 13, 2019

Published: May 16, 2019

Copyright () 2019 by author(s) and Scientific Research Publishing Inc. This work is licensed under the Creative Commons Attribution International License (CC BY 4.0).

http://creativecommons.org/licenses/by/4.0/

\section{(c) () Open Access}

\begin{abstract}
In the present study, we explore an environmental tax reform for Austria as an instrument to achieve the main objectives of the current Austrian Climate and Energy Strategy \#mission2030. Our concept aims at a dual objective of reducing $\mathrm{CO}_{2}$-eq emissions, while simultaneously further triggering innovation processes of the Austrian industry, resulting in a transfer of benefits to society. The focused measures at the national level to achieve climate protection comprise an increase of the mineral oil tax and the introduction of $\mathrm{CO}_{2}$-eq taxation for non-EU-ETS sectors. These taxes create revenues which are recycled through 1) reductions of non-wage labor costs for companies, 2) compensation transfers for private households of low- and middle-income groups, 3) investment in research and innovation for industry and 4) investments in key technologies to advance \#mission2030, such as alternative propulsion systems (electric, $\mathrm{H}_{2}$ ), and the use of biomethane for space heating and thermal renovation. Results of simulations for the period 2020 to 2025 via a macro-sectoral model display the potential for multiple dividends if the revenues are reused this way. Furthermore, besides offering significant reductions of $\mathrm{CO}_{2} \mathrm{e}$ emissions, the proposed reform triggers positive impacts on GDP, employment, and private consumption, thereby ensuring social compatibility.
\end{abstract}

\section{Keywords}

Environmental Tax Reform, Revenue Recycling, Climate-Friendly

Investment, Equity, Macroeconomic Simulation

\section{Introduction}

The increasingly alarming rate of environmental dysfunction and degradation 
and the resulting costs for achieving climate protection goals require a reorientation of existing climate mitigation policies towards the use of environmental and green taxes. On the one hand, these taxes create revenues that can theoretically be used by governments to increase their spending on environmental protection or for a more efficient management of natural resources. On the other hand, deficits of existing fiscal regimes such as high burdens derived from labor taxes and social contributions demand a fundamental transformation of the tax system. The substantial impact that these and other fiscal constraints have on both national budgets and the target population(s) are a contentious topic of debate in the public domain, and are increasingly finding their way back into the core of public opinion. As such, they merit a thorough analytical contribution in order to validate and inform a more accurate and refined factual public debate.

The combination of the taxation of the production factors "environment" and "labor" leads to the concept of environmental tax reform (ETR) developed by Binswanger et al. [1] [2]. This idea covers a (gradual) government spending-neutral shifting of taxes from the production factor "labor" to the production factor "environment". On the basis of the double-dividend theory, revenues generated by green taxation can be recycled back into the system so as to positively stimulate macroeconomic variables. The ecological dividend corresponds to the improvement of the state and function of the natural environment, whereby the economic dividend is based on increasing economic efficiency by the reduction of non-wage labor costs and income taxes. This may then contribute to increased job creation or to reduced unemployment [3] [4] [5].

The distributional impacts on industries and households can be central, since these groups habitually provide high levels of political influence. The introduction of environmental taxes will place a direct burden on households and businesses, while the benefits of the reform-the reduction of environmental pollutants-will not be detectable within the most immediate future and their accountability will be long term. This means that politicians who are maximizing their popularity [6] will have to bear the costs immediately while the benefits will occur in the long run making it difficult for the voter to understand why he should support an environmental tax reform. For the average short-sighted individual voter, direct and short-term concerns such as job security and economic well-being are often of greater and more immediate concern than long-term ecological objectives [7] [8]. This broader timeframe gives the environmental benefits the character of a public good: Everyone benefits from it but some individuals bear the costs. A socially acceptable redistribution of the tax revenues should be chosen as lower income earners, for whom the share of expenditure on energy is particularly high, would face a higher tax burden. The political feasibility of an ecological tax reform depends on several conditions [9]: 1) The ecological tax reform must be revenue-neutral. 2) Unemployment should not 
increase or decrease in the long term. 3) The tax revenue must have a socially-compatible redistribution throughout the target population. Hence, developing policies that operationalize environmental objectives while circumventing significant cost burdens on key industries and households can enhance political feasibility [10].

In this context, our study aims to analyze the contributions of an ETR within the framework of the current Austrian climate and energy strategy \#mission2030. The strategy of \#mission2030 is based on three pillars-security of supply, competitiveness of the economy, and affordable energy prices. These three pillars are in line-with the EU's priorities and should be achieved through the implementation of carbon-neutral technologies [11]. This ongoing transformation process of Austria's energy system poses major challenges for sectors of the Austrian society and economy. However, it offers considerable opportunities to promote technology innovation in both areas. We focus on an ETR for Austria which aims at regulating $\mathrm{CO}_{2}$-eq emissions in sectors outside the European Emissions Trading Scheme (EU ETS) and provides revenue recycling for selected key technologies of \#mission2030 and innovation processes of Austrian industry and society.

With regard to the assessment of an ETR and resulting double-dividend effects in Austria, various studies analyzed the different dividends of the introduction of $\mathrm{CO}_{2}$ taxes and the increase of existing energy taxes on macroeconomic parameters such as gross domestic product (GDP) and employment, ecological impacts such as $\mathrm{CO}_{2}$-eq emissions, and distributional impacts [12] [13] [14] [15]. Our approach focuses on how Austria can reconcile continuous economic growth with $\mathrm{CO}_{2}$-eq reductions, while simultaneously guaranteeing the implementation of key target technologies within the current transformation process envisioned under \#mission2030 which distinguishes this study from past assessments for Austria.

The paper is structured as follows: Section 2 describes the developments and targets of $\mathrm{CO}_{2}$-eq emissions in the framework of \#mission2030. Section 3 outlines briefly the methodology applied to analyze the macroeconomic effects of an ETR in Austria. In Section 4, we propose a concrete ETR which supports innovative technologies for $\mathrm{CO}_{2}$-eq reduction and provides economic growth, ecological stewardship and social acceptability. The results of the macroeconomic simulation are presented in Section 5. Section 6 concludes.

\section{Background}

\subsection{Environmental Tax Revenues in Austria}

The common approach of the European Commission, the OECD and the International Energy Agency defines environmental taxes as taxes whose basis of assessment has a damaging effect on the environment. European statistics differentiate four different classifications of environmental taxes pertaining to energy, transport, pollution and natural and mineral resources. 
Based on data of Statistik Austria [16], the volume of revenues stemming from environmental taxes in Austria shows a dynamic development in the long-term from 1995 to 2016, as displayed in Table 1. The total revenue obtained from environmental taxes was around $€ 4.2$ billion in 1990 and $€ 9.1$ billion in 2016 . Over the entire period, energy taxes, with an average share of around $60 \%$, represented by far the biggest share of environmental taxes. Their resulting revenue has more than doubled since 1995 until 2016 to $€ 5.3$ billion. This evolution is mainly due to the revenues obtained from the mineral oil tax, which account for the majority of energy taxes (83\% on average for 2005 until 2016), and whose high revenue growth was largely determined by a significant increase of the transport sector. Taxes collected in connection with transport have also increased strongly. On average they account for $31 \%$ of the environmental tax revenue. The remaining $9 \%$ of environmental tax revenues comprise resource and pollution taxes. The latter are still insignificant with a share of less than $1 \%$ and their volume has tended to decline in recent years. The significance of the revenue obtained from environmental taxes within a country can be displayed by the indicator of "environmental tax share" in total tax revenues (including social contributions). Over the period between 1995 to 2016, the share of environmental tax of the total tax revenue rose from $5.5 \%$ to $6.0 \%$. In 2005 , the share was at $6.6 \%$ [16]. In other words, despite the increasing volume of environmental tax revenues, their share has remained stagnant and their relative importance has recently decreased.

\section{2. $\mathrm{CO}_{2}$-eq Emissions in Austria and Targets of the National Climate and Energy Strategy \#mission2030}

Data from the Austrian Federal Environmental Agency [17] reveals that Austria emitted 79.7 million tons of $\mathrm{CO}_{2}$-eq $\left(\mathrm{MtCO}_{2}\right.$-eq) in 2016. As depicted in Table 2, these developments induced an increase in emissions of $1.3 \%$ compared to the 1990 Kyoto base year levels, and an increase of 1.0\% compared to 2015 levels. Emissions from the non-emissions trading sector in 2016 amounted to 50.6 $\mathrm{MtCO}_{2}$-eq and thus have increased by $2.7 \%$ since 2015 . The reasons for this

Table 1. Historical development of revenues by environmental taxation in Austria.

\begin{tabular}{cccccccc}
\hline & & 1995 & 2000 & 2005 & 2010 & 2015 & 2016 \\
\hline Energy taxes & $b n €$ & 2479 & 3288 & 4350 & 4585 & 5216 & 5285 \\
Transport taxes & $b n €$ & 1300 & 1795 & 2156 & 2265 & 2908 & 3018 \\
Resource taxes & $b n €$ & 383 & 453 & 535 & 603 & 682 & 691 \\
Pollution taxes & $b n €$ & 21 & 72 & 46 & 51 & 56 & 58 \\
Total & bn $€$ & 4182 & 5608 & 7087 & 7505 & $\mathbf{8 8 6 2}$ & 9052 \\
Share of overall & $\%$ & 5.5 & 6.0 & 6.6 & 6.0 & 5.9 & 6.0 \\
tax revenues & & & & & & & 2.5 \\
Share of nominal GDP & $\%$ & 2.4 & 2.6 & 2.8 & 2.5 & 2.6 & 2.5 \\
\hline
\end{tabular}

${ }^{a}$ Including social contributions. Source: Statistik Austria [16]. 
Table 2. Historical development of $\mathrm{CO}_{2}$-eq emissions in Austria and targets of \#mission 2030 .

\begin{tabular}{cccccccc}
\hline & 1990 & 2005 & 2014 & 2015 & 2016 & $\begin{array}{c}\text { Target 2030 } \\
\text { \#mission2030 }\end{array}$ & $\begin{array}{c}\Delta \text { Target 2030 } \\
\text { \#mission2030 } \\
\text { (compared to } \\
\text { 2016) }\end{array}$ \\
\hline $\begin{array}{c}\text { Energy and } \\
\text { Industry }\end{array}$ & 36.5 & 42.1 & 33.8 & 35.7 & 35.3 & - & \\
Transport & 13.8 & 24.6 & 21.7 & 22.1 & 23.0 & 15.7 & -14.3 \\
Buildings & 13.0 & 12.5 & 7.7 & 8.0 & 8.1 & 5.0 & -3.1 \\
Agriculture & 9.5 & 8.2 & 8.1 & 8.0 & 8.2 & - & \\
Waste & 4.3 & 3.4 & 3.1 & 3.0 & 3.1 & - & -20.4 \\
management & & & & & & & \\
F-gases & 1.7 & 1.8 & 2.0 & 2.0 & 2.1 & - & -14.2 \\
Total & 78.8 & $\mathbf{9 2 . 6}$ & 76.4 & 78.9 & 79.7 & 59.3 & - \\
EU ETS & & 35.8 & 28.1 & 29.5 & 29.1 & & \\
Non-EU ETS & & 56.8 & 48.3 & 49.4 & 50.6 & 36.4 & \\
\hline
\end{tabular}

Sources: Federal ministry for sustainability and tourism, Austrian ministry for transport, innovation and technology [11]; Austrian federal environmental agency [17].

development are, in particular, the strong increase of fossil fuel use in the transport sector and higher heating requirements of buildings due to weather conditions [17]. Austria's current climate and energy strategy \#mission2030 aims to reduce domestic $\mathrm{CO}_{2}$-eq emissions by $36 \%$ by 2030 compared to 2005 levels. For the non-EU ETS sector, a level of $36.4 \mathrm{MtCO}_{2}$-eq is aimed at for 2030, which implies a reduction of around $28 \%$. Increasing energy efficiency and the intensive usage of renewable energy sources are the main strategies for achieving the abovementioned reduction [11]. Further, the focus of $\mathrm{CO}_{2}$-eq abatement relies particularly on the transport and building sectors, where the greatest reduction potential exists. With a share of $46 \%$ of total $\mathrm{CO}_{2}$-eq emissions (non-EU ETS sector), transport is currently the sector with the highest $\mathrm{CO}_{2}$-eq emissions. To meet the overall target by 2030, the \#mission2030 strategy foresees a reduction by 7.2 to $15.7 \mathrm{MtCO}_{2}$-eq in 2030 . The expansion of the pioneering role in vehicle propulsion using electricity or other alternative means of combustion, and public transport are identified as possible measures in \# mission2030 [11]. Therefore, a carbon-reduction pathway should be adopted which is compatible with the goal of a fossil-free mobility by 2050 . Additionally, significant potential for carbon emissions reduction is expected in the building sector. Possible measures include thermal renovation-which can give economic impulses to domestic industries - the abandonment of fossil fuels and the switch to renewable energy sources in new buildings, and highly efficient district heating systems for existing buildings. This would reduce carbon emissions by $5 \mathrm{MtCO}_{2}$-eq by 2030 [11]. In the energy and industry sector (excluding installations covered by the EU ETS), an innovation boost should be triggered by the promotion of energy effi- 
ciency measures and the widest possible transition to renewable energy sources or electricity-based processes. In the agricultural sector, $\mathrm{CO}_{2}$-eq reductions are planned through the use of renewable fuels and efficient propulsion systems in agricultural machinery and fertilizer applications. With regard to waste management and fluorinated greenhouse gases, EU legislation (F-gas regulation) and Austrian measures (implementation of the Circular Economy Package) are seen as instruments to achieve the necessary carbon emission reductions [11].

\section{Methodological Approach}

The effects of the proposed environmental tax reform (ETR) were examined using the macro econometric multi-sectoral model MOVE2. The time series-based simulation model MOVE and its successor MOVE2 were developed at the Energieinstitut at the Johannes Kepler University in Linz (Austria). These models allow the estimation of various economic and structural changes within Austria and the analysis of economic, environmental and energy-related effects based on different political and/or investment decisions. MOVE2 focuses on energy-related issues, which enables comprehensive and complex studies of all aspects of the national energy market. All endogenous variables are explained by stochastic equations, and the economic relationships are revealed through the use of time series. Therefore, the model draws on the economic structures of the past to simulate certain changes in future scenarios. The specified theory-based equations are estimated using econometric methods (seemingly unrelated regressions) and implemented in the model structure. In addition to the stochastic equations (or, in the economic context "behavioral equations") the model incorporates identities of equations, which specify the model. MOVE2 contains 330 equations and 476 variables to perform the simulations. The economic module covers 13 economic sectors including private households. Within the energy module, 24 energy sources are modeled. Since the use of energy implicates the generation of GHG emissions, MOVE2 also contains an emissions tool which calculates the changes in emissions due to the energy consumption in Austria. In particular, the development and interactions of the macroeconomic variables, i.e. gross domestic product, investments, employment, and private consumption are displayed. Regarding the interpretation of the results, we must emphasize that the simulation result displays the difference of the two development paths of the model, namely the difference between the "business-as-usual" scenario and the "simulation" scenario representing the implementation of the proposed ETR.

For reasons of space, the reader is referred to Refs. [18] [19] for detailed information on the model's structure and methodology. Concrete applications of the simulation model can be found in Refs. [20] [21] [22].

\section{Concept of an Environmental Tax Reform for Austria}

\subsection{Revenue Raising Components}

On the revenue side, an increase of the mineral oil tax on diesel and petrol by 
$€ 0.1 /$ liter and the introduction of a $\mathrm{CO}_{2}$-eq tax in the non-EU ETS sector (excluding the transport sector) of $€ 25 /$ tonne $\mathrm{CO}_{2}$-eq were defined as revenue raising instruments of the ETR. These measures are aimed at making the use of fossil fuels and the use of $\mathrm{CO}_{2} \mathrm{e}$-containing energy sources more expensive and allocating the external effects of emissions of $\mathrm{CO}_{2}, \mathrm{CH}_{4}$ and $\mathrm{N}_{2} \mathrm{O}$ to the polluters. Currently, the following fuel tax rates are applied for diesel and petrol in Austria: 1) $397 € / 1000$ liters of diesel containing at least $66 \mathrm{l}$ of biogenic materials and a maximum sulfur content of $10 \mathrm{mg} / \mathrm{kg}$ (otherwise: $425 € / 1000$ liters of diesel) and 2) $482 € / 1000$ liters of petrol containing at least $46 \mathrm{l}$ of biogenic materials and a maximum sulfur content of $10 \mathrm{mg} / \mathrm{kg}$ (otherwise: $515 € / 1000$ liters of petrol). Further, targeted carbon taxation has been applied in ten EU Member States: Denmark, Estonia, Finland, France, Ireland, Latvia, Portugal, Slovenia, Sweden and Poland. However, these $\mathrm{CO}_{2}$ taxes cover only a small share of the overall tax rate on energy and are below $10 € / t \mathrm{CO}_{2}$. Sweden and Finland provide significant exemptions with $\mathrm{CO}_{2}$ components of $118 € / t \mathrm{CO}_{2}$ and $62 € / t \mathrm{CO}_{2}$, respectively [23]. In consideration of previous simulation analyses of $\mathrm{CO}_{2} \mathrm{e}$ taxation for Austria [14] [15], the introduced explicit carbon tax amounts to $25 € / \mathrm{t} \mathrm{CO}_{2} \mathrm{e}$ in the present analysis.

Simulation results show that the increase of the mineral oil tax on diesel and petrol and the introduction of a $\mathrm{CO}_{2}$-eq tax generate additional revenues of approx. $€ 1.8$ billion in the period from 2020 to 2025 . In order not to weaken economic growth, revenues are recycled to regulated companies and households.

\subsection{Revenue Recycling Components}

Through the revenue recycling scheme, the purchasing power can be maintained and growth stimuli for the economy can be generated. The implementation of investment measures triggering an increase in the use of renewable energies and energy efficiency is an important pillar of the ETR. As a result of their investment character, positive economic multi-round effects may result. The revenue recycling scheme includes the reduction of non-wage labor costs for companies as well as compensation transfers to private households. In addition, further revenue recycling measures involve investment in research, development and innovation, and investment in key technologies (vehicle propulsion using electricity and renewable $\mathrm{H}_{2}$, use of biomethane for space heating, thermal renovation) for the implementation of the Austrian climate and energy strategy \#mission 2030 .

\subsubsection{Reduction of Non-Wage Labor Costs}

Reducing non-wage labor costs can decrease unit labor costs, thus weakening the substitution of labor with capital and limiting illegal work. This results in positive employment effects, which can lead to an increase in private consumption through a higher wage bill. In addition, a reduction in non-wage labor costs induces an improvement in international competitiveness. These developments play a significant role in the economic growth of a small, open economy with 
intensive foreign trade such as Austria. For our simulation analysis, the amount to reduce non-wage labor costs is set to $€ 250$ million per year.

\subsubsection{Compensation Payments for Private Households}

Depending on the respective energy consumption and mobility behavior, a compensation transfer system for private households is considered, which can mitigate the extra burden on low and middle-income households in particular. Taking into account data of Statistic Austria [24] on the income tertiles and energy use of households for purposes of use (room heating, hot water, cooking and other) reveals that the $\mathrm{CO}_{2}$-eq tax implies yearly additional burdens of $€ 73$ for low-income households, €93 for mid-income households and €122 for high-income households. Furthermore, private households face additional costs due to the increase of the mineral oil tax on diesel and petrol products. The approximation of the possible burden relies on data from Statistic Austria on the number of diesel and petrol cars of private households, their fuel consumption and average annual mileage of first-time passenger cars [25]. An average annual mileage of approx. 13,800 km and thus annual additional costs of $€ 129$ per first car per household can be derived.

Based on these calculations and the assumption of 3.9 million households in Austria, an annual compensation transfer of $€ 250$ for the "low" and "middle household income" tertiles can provide these two with complete compensation for additional costs as well as an increase in net income. For high-income households, however, the ETR would imply higher costs.

\subsubsection{Investment in Research and Innovation for Further Development and Strengthening of the Industry}

The core objective of research funding is to develop innovative and holistic solutions for challenges stemming from a low-carbon energy transition, and to introduce them quickly into the market. The aim is to increasingly adopt new trends (e.g. digitalization, energy storage) to maintain and expand technological competencies for the transformation process in the energy sector of industry, and to improve export opportunities for innovative energy technologies. The Austrian energy-intensive industry is one of the most energy-efficient in the world and has already invested in a large number of emission-reducing measures in the past. Thus, further efficiency measures represent a major challenge for companies and therefore imply high investments [26]. At the same time, the industry sector plays a significant role for economic growth and foreign trade in Austria. The production of goods in 2016, at around $€ 54$ billion, generated about $27 \%$ of the Austrian gross value added. Hence, adaptation measures are needed to circumvent competitive disadvantages for sectors with high energy cost and high external trade intensities (such as metal production and processing, chemical industry) as part of the ETR. This fact is addressed by recycling $€ 250$ million per year for investment in research and innovation in the industry sector within the simulation analysis. 


\subsubsection{Investments in Key Technologies of Austria's Climate and Energy Strategy \#mission 2030}

With regard to the objectives set out in \#mission2030, we implement investment subsidies for initiatives on alternative propulsion systems (electric, $\mathrm{H}_{2}$ ), the use of biomethane in the space heating sector, and thermal renovation, as elements of the revenue recycling scheme.

Within the promotion of alternative propulsion systems, we provide a direct takeover of the additional investment costs for 20,000 electric vehicles per year, 5000 hydrogen vehicles per year, and the electricity charging infrastructure and renewable hydrogen production required. Drawing from Refs. [27] [28] [29], average investment cost of $€ 200$ million per year arise and about 140 million liters of fossil fuels (petrol, diesel) are substituted in 2030 by 265 GWh electricity and $280 \mathrm{GWh}$ renewable $\mathrm{H}_{2}$, respectively.

Based on the fact that natural gas is an important source of energy in Austria and a densely developed natural gas distribution network is already in place, \#mission2030 advocates for the successive substitution of natural gas by $\mathrm{H}_{2}$ and biogas alternatives [11]. The analyzed ETR also covers the feed-in of $2400 \mathrm{GWh}$ of biomethane per year in the households' space heating sector, as a substitute for natural gas and heating oil. Assuming biomethane production costs of 0.15 $€ / \mathrm{kWh}$ leads to average costs of $€ 100$ million per year.

A further important flagship project of the \#mission2030 strategy is thermal renovation of buildings. Against the background that currently space and water heating in residential and commercial buildings cause about $16 \%$ of Austrian $\mathrm{CO}_{2}$-eq emissions in sectors outside the EU ETS, thermal renovation offers great potential for decreasing the energy demand in those areas [11]. The budget alocated for the recycling of the revenues derived from this building renovation measures amounts to $€ 350$ million per year, and accounts for energetic and economic parameters of thermal refurbishment in Austria [30].

\subsection{Overview}

The analyzed ETR for the period 2020-2025 covers revenue raising and recycling measures as presented in Table 3. Special emphasis was placed on revenue neutrality.

\section{Simulation Results}

\subsection{Macroeconomic Impacts}

The recycling of the revenues generated by the proposed environmental tax reform (ETR) to different sectors of the Austrian economy provides incentives for climate-friendly consumption and investment. The dynamic simulation analysis for the period 2020-2025 reveals positive macroeconomic effects in the form of a higher gross domestic product (GDP) and an increase in employment. These developments are mainly the result of investment impulses and an increase of consumption of private households. In the short term (from 2020 to 
Table 3. Revenue and recycling components of an ecologically effective, socially acceptable and economically innovative environmental tax reform.

\begin{tabular}{cc}
\hline Revenue raising components & $\varnothing(2020-2025)$ \\
\hline $\begin{array}{c}\text { Increase of mineral oil tax }(0.15 € / 1 \text { petrol and diesel) } \\
\text { Tntroduction of } \mathrm{CO}_{2} \text { e tax in the non-EU ETS sector (excl. transport) }\end{array}$ & $+1123 \mathrm{~m} €$ per year \\
$+656 \mathrm{~m} €$ per year \\
Revenue recycling components & $+1779 \mathrm{~m} €$ per year \\
\hline Reduction of non-wage labor costs & $-250 \mathrm{~m} €$ per year \\
Compensation payments for private households & $-650 \mathrm{~m} €$ per year \\
Investment in research and innovation for the industry & $-250 \mathrm{~m} €$ per year \\
Investments in key technologies of \#mission 2030 & $-650 \mathrm{~m} €$ per year \\
Total & $-1800 \mathrm{~m} €$ per year \\
\hline
\end{tabular}

2021), the higher cost burden for households is reflected in a decline in private consumption. In terms of employment, a decline is evident in 2020 due to the higher burden on economic activities as a result of the fiscal measures. In the following years, however, the positive economic development leads to an increase in net employment. Table 4 and Figure 1 illustrate these results.

As displayed in Figure 2, the sectoral degree of aggregation offered in the model does not reveal any additional burdens of energy-intensive areas in terms of lower investment activity. These results show that the intention of the proposed ecological tax reform-to lower the burden on energy-intensive sectors of the economy through innovation and investment subsidies-is fulfilled.

\subsection{Environmental Impacts}

There is also an incentive-based environmental effect displayed by a significant decline in $\mathrm{CO}_{2}$-eq emissions. The increase in energy prices for petrol and diesel and the implementation of a $\mathrm{CO}_{2}$-eq tax combined with the investment promotion of key technologies and innovative production processes lead to a significant reduction of GHG emissions averaging 3.3 $\mathrm{MtCO}_{2}$-eq per year. Based on the revenue-raising and recycling components of the ETR defined in Section 4, the following drivers for $\mathrm{CO}_{2}$-eq mitigation can be identified and are displayed in Figure 3:

- Reduced use of fossil energy in the space heating sector through the use of biomethane and the implementation of thermal renovations;

- impact of the $\mathrm{CO}_{2}$-eq tax and innovation support on fossil energy consumption in households and the economy;

- Reduced use of fossil fuels through increased mortality rates and investment incentives for alternative propulsion (e- and $\mathrm{H}_{2}$ mobility) on household and company levels.

As mentioned in Section 2, the Austrian Climate and Energy Strategy \#mission2030 aims to achieve a GHG emissions level of $59.3 \mathrm{MtCO}_{2}$-eq by 2030 [11], 
Table 4. Macroeconomic impacts in Austria of an ecologically effective, socially acceptable and economically innovative environmental tax reform, 2020-2025.

\begin{tabular}{ccccccccc}
\hline & & 2020 & 2021 & 2022 & 2023 & 2024 & 2025 & $\varnothing$ \\
$(2020-2025)$
\end{tabular}

Additional direct, indirect and induced effects compared to a reference scenario where no ETR is applied. Rounded values. Source: Simulation via MOVE2 [15].
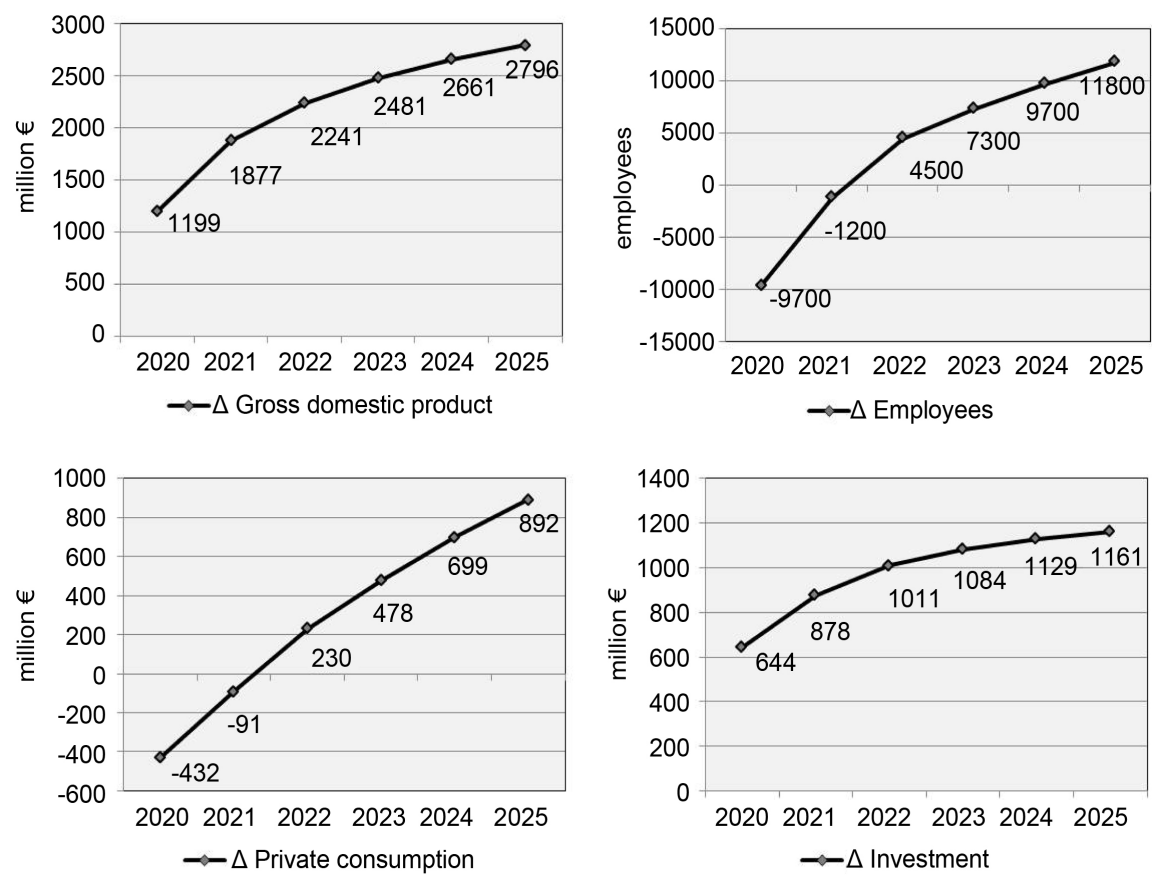

Figure 1. Macroeconomic impacts in Austria due to an ecologically effective, socially acceptable and economically innovative environmental tax reform, 2020-2025.

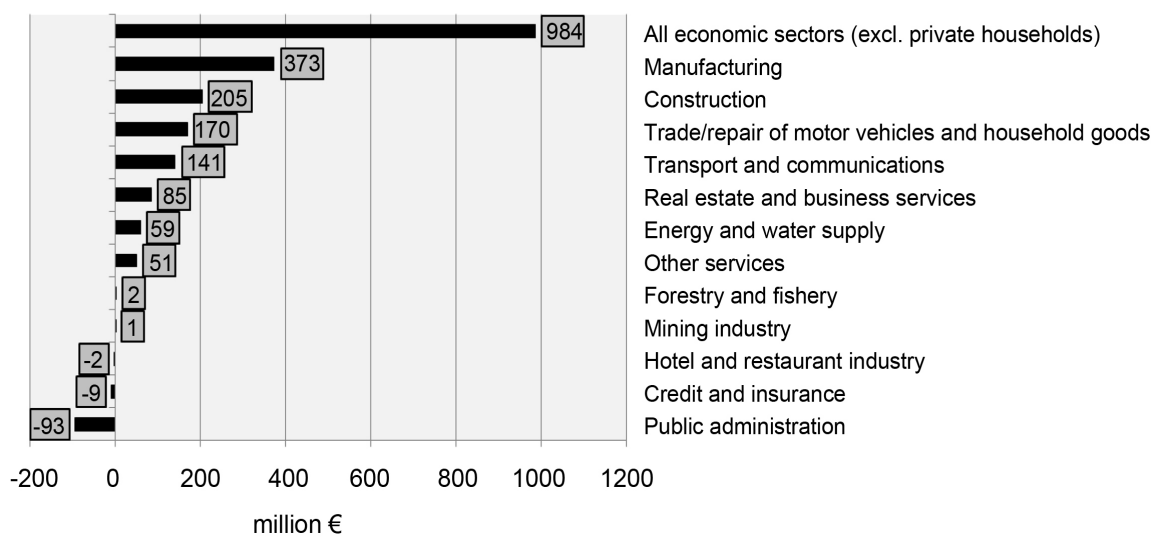

Figure 2. Impacts on investments in Austria on the sectoral level due to an ecologically effective, socially acceptable and economically innovative environmental tax reform, average values for 2020-2025. 


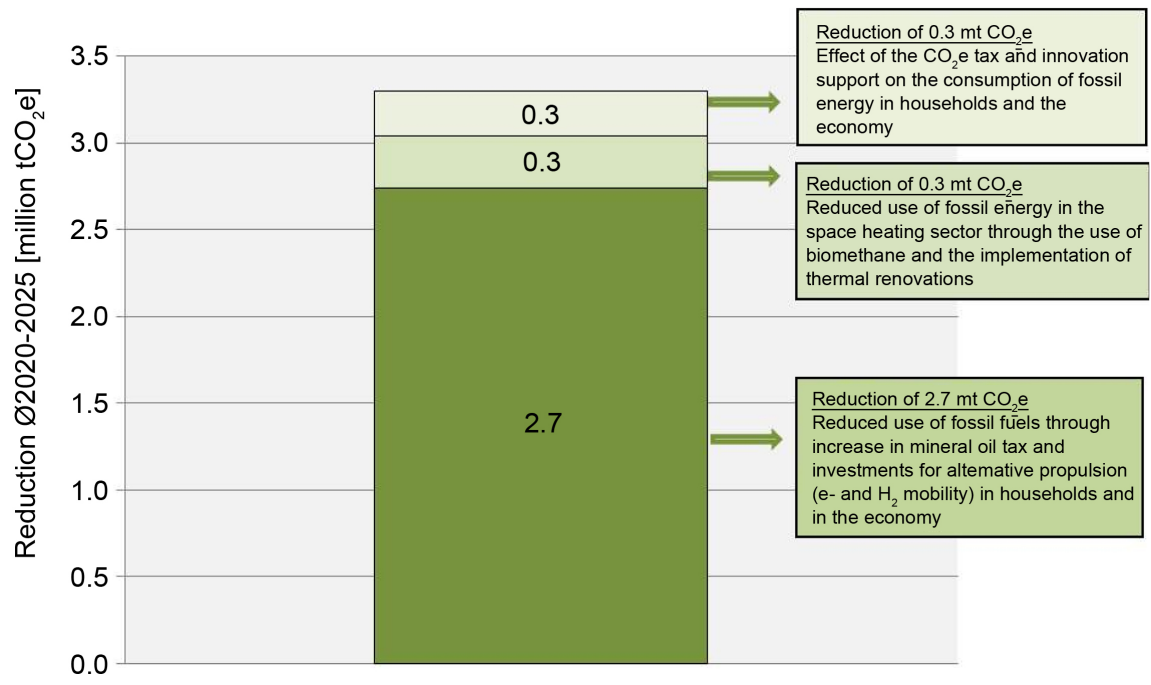

Figure 3. Drivers of $\mathrm{CO}_{2}$-eq reduction of the proposed environmental tax reform for Austria, average values for 2020-2025.

which implies a reduction of $20.4 \mathrm{MtCO}_{2}$-eq. Within this context, the avoided GHG emissions of the proposed ETR would represent an average of around 36\% of the required abatement target for 2030 during the period 2020-2025. Figure 4 illustrates these findings.

\subsection{Fiscal Impacts}

The government's budget also faces positive effects. The proposed ETR is designed to be revenue-neutral, which implies that the revenue generated on the revenue side roughly corresponds to the monetary reimbursements to households and the economy on the costs side. Nevertheless, there are additional revenues from taxes (value added tax, payroll tax) and social security contributions as a result of the impulses on the level of employment and thus on the total wage bill and private consumption as shown in Table 5.

\section{Conclusions}

The paper explores how an environmental tax reform (ETR) in Austria can contribute to reduce $\mathrm{CO}_{2}$-eq emissions and to implement selected key measures of the current Austrian Climate and Energy Strategy \#mission2030, leading to a higher use of renewable energy and increased penetration of energy efficiency. Drawing from findings in economic theory and studies of ETR in Austria, it is necessary to design a system that corrects distributional problems and maintains the right environmental and economic incentives, while ensuring social acceptance and political feasibility.

At the national level, an assessment of the macroeconomic, ecological and fiscal impacts of ETR is carried out for the period 2020 to 2025. The ETR simulated in our study comprises imposing an increase on the mineral oil tax of $0.15 €$ per liter of diesel and petrol (excl. VAT) and a $\mathrm{CO}_{2}$-eq tax of $25 € / \mathrm{tCO}_{2}$-eq for the 


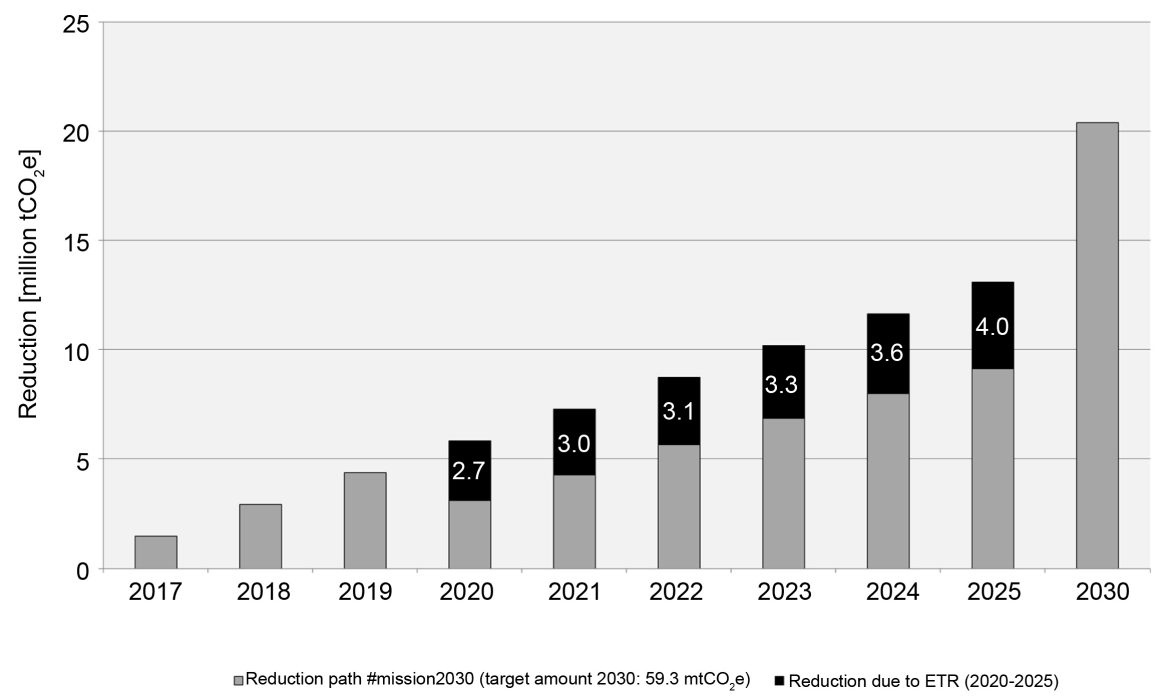

Figure 4. Contribution of the proposed environmental tax reform in the period 2020-2025 to the targeted $\mathrm{CO}_{2}$-eq reduction for Austria under \# mission 2030 .

Table 5. Fiscal impacts in Austria of an ecologically effective, socially acceptable and economically innovative environmental tax reform, 2020-2025.

\begin{tabular}{cccccccccc}
\hline & 2020 & 2021 & 2022 & 2023 & 2024 & 2025 & $\begin{array}{c}\emptyset \\
(2020-2025)\end{array}$ \\
\hline $\begin{array}{c}\Delta \text { Government expenditures due to } \\
\text { recycling components }\end{array}$ & $m €$ & 1787 & 1795 & 1804 & 1812 & 1820 & 1829 & 1808 \\
$\begin{array}{c}\Delta \text { Public revenues due to mineral oil } \\
\text { tax increase and } \mathrm{CO}_{2} \mathrm{e} \text { tax }\end{array}$ & $m €$ & 1865 & 1801 & 1744 & 1706 & 1672 & 1639 & 1738 \\
$\begin{array}{c}\Delta \text { Value added tax revenues due } \\
\text { to private consumption } \\
\text { and investments }\end{array}$ & $m €$ & 151 & 253 & 317 & 356 & 385 & 405 & 311 \\
$\begin{array}{c}\Delta \text { Income tax revenues } \\
\text { Incovernment balance }\end{array}$ & $m €$ & -72 & -9 & 33 & 54 & 72 & 87 & 28 \\
$\quad$ for covering deficits & $m \epsilon$ & 157 & 250 & 291 & 305 & 308 & 303 & 269 \\
\hline
\end{tabular}

Additional direct, indirect and induced effects compared to a reference scenario where no ETR is applied. Rounded values. All tax revenues are adjusted for demand effects. Source: Simulation via MOVE2 [15].

non-EU ETS sector (excl. transport), as well as a revenue recycling scheme focusing on compensations for low- and middle-income household groups and the industry and triggering alternative propulsion systems (electric, $\mathrm{H}_{2}$ ), the use of biomethane for space heating and thermal renovation via investment subsidies. The simulation results show that, at the aggregated national level, the ETR would generate positive impacts on the gross domestic product, employment, private consumption and investment. A significant reduction of $\mathrm{CO}_{2}$-eq emissions averaging $3.3 \mathrm{MtCO}_{2}$-eq per year is achieved by the implementation of targeted fiscal instruments, key clean technologies and innovative production and energy efficiency processes.

However, sectors of the economy and household groups may be affected dif- 
ferently. The results show that the intention of lowering the burden on energy-intensive sectors of the economy through innovation and investment subsidies via revenue recycling is accomplished by the proposed ETR. Further, lowand middle-income households could be able to increase their net income in addition to full coverage of additional cost burdens due to the direct compensation payments.

It should be noted that the measures and volumes analyzed within the study are to be understood as indicative in order to exemplify the possible positive macroeconomic and ecologic effects stemming from such an environmental tax reform as outlined in this study. The concrete revenue raising and recycling components have to be decided through the corresponding political process and legislative procedures. However, the study provides another indication that at the national level an environmental tax reform is a meaningful tool for creating a more accurate, efficient, and targeted domestic climate and energy policy.

\section{Acknowledgements}

The authors thank Robert Tichler and Horst Steinmüller for discussions on the design of the examined environmental tax reform, Cristian Pons-Seres de Brauwer for drafting the paper and an anonymous reviewer for valuable comments on an earlier version of the paper. Financial support of the Energieinstitut at the Johannes Kepler University of Linz is gratefully acknowledged.

\section{Conflicts of Interest}

The authors declare no conflicts of interest regarding the publication of this paper.

\section{References}

[1] Binswanger, H.C., Geissberger, W. and Ginsburg, T. (1979) Wege aus der Wohlstandsfalleder NAWU-Report: Strategien gegen Arbeitslosigkeit und Umweltzerstörung. Frankfurt.

[2] Binswanger, H.C., Frisch, H. and Nutzinger, H.G. (1983) Arbeit ohne Umweltzerstörung: Strategien einer neuen Wirtschaftspolitik. Frankfurt.

[3] Goulder, L.H., Parry I.W.H. and Burtraw, D. (1997) Revenue-Raising versus Other Approaches to Environmental Protection: The Critical Significance of Preexisting Tax Distortions. The Rand Journal of Economics, 28, 708-731. https://doi.org/10.2307/2555783

[4] Pearce, D. (1991) The Role of Carbon Taxes in Adjusting to Global Warming. The Economic Journal, 101, 938-948. https://doi.org/10.2307/2233865

[5] Weizsäcker, E.U. and Jesinghaus, J. (1992) Ecological Tax Reform. Zed Books, London.

[6] Brennan, G. and Buchanan, J. (1980) The Power to Tax: Analytical Foundations of a Fiscal Constitution. Cambridge University Press, Cambridge.

[7] Schneider, F. and Volkert, J. (1999) No Chance for Incentive-Oriented Environmental Policies in Representative Democracies? A Public Choice Analysis. Ecological Economics, 31, 123-138. https://doi.org/10.1016/S0921-8009(99)00047-6 
[8] Kirchgässner, G. and Schneider, F. (2003) On the Political Economy of Environmental Policy. Public Choice, 115, 369-396. https://doi.org/10.1023/A:1024289627887

[9] Schneider, F. (1999) Induzieren ökologische Steuerreformen einen Lenkungseffekt oder nur volle Staatskassen? Einigevolkswirtschaftliche Überlegungen. Johannes Kepler University Linz, Linz.

[10] Kollmann, A. and Schneider, F. (2010) Why Does Environmental Policy in Representative Democracies Tend to Be Inadequate? A Preliminary Public Choice Analysis. Sustainability, 12, 3710-3734. https://doi.org/10.3390/su2123710

[11] Federal Ministry for Sustainability and Tourism and Austrian Ministry for Transport, Innovation and Technology (2018) Mission2030: Die Klima- und Energiestrategie der Österreichischen Bundesregierung. https://mission2030.info/

[12] Breuss, F. and Steininger, K. (1995) Reducing the Greenhouse Effect in Austria. A General Equilibrium Evaluation of $\mathrm{CO}_{2}$-Policy-Options. EI Working Papers, Vienna.

[13] Kirchner, M., Sommer, M., Kratena, K., Kletzan-Slamanig, D. and Kettner-Marx, C. (2019) $\mathrm{CO}_{2}$ Taxes, Equity and the Double Dividend: Macroeconomic Model Simulations for Austria. Energy Policy, 126, 295-314. https://doi.org/10.1016/j.enpol.2018.11.030

[14] Kletzan, D., Köppl, A. and Kratena, K. (2008) Ziele und Optionen der Steuerreform: Optionen für eine Ökologisierung des österreichischen Steuersystems. Austrian Institute ofEconomic Research, Vienna.

[15] Schneider, J. and Wahlmüller, J. (2015) Eine ökologische und soziale Steuerreform für Österreich. Ergebnisse einer Modellierung der Gesellschaft für wirtschaftliche Strukturforschung. Umweltbundesamt, GLOBAL 2000, Vienna.

[16] Statistik Austria (2019) Ökosteuern. http://statistik.gv.at/web_de/statistiken/energie_umwelt_innovation_mobilitaet/ene rgie_und_umwelt/umwelt/oeko-steuern/index.html

[17] Austrian Federal Environmental Agency (2018) Klimaschutzbericht 2018. REP-0660, Vienna.

[18] Tichler, R. (2009) Optimale Energiepreise und Auswirkungen von Energiepreisveränderungen auf die oö. Volkswirtschaft. Analyse unter Verwendung des neu entwickelten Simulationsmodells MOVE. Energiewissenschaftliche Studien, Linz.

[19] Goers, S., Baresch, M., Tichler, R. and Schneider, F. (2015) MOVE2: Simulation Model of the (Upper) Austrian Economy with a Special Focus on Energy Including the Socio-Economic Module MOVE2Social-Integration of Income, Age and Gender. Energieinstitut at the Johannes Kepler University, Linz.

[20] Bointner, R., Biermayr, P., Goers, S., Streit-Maier, J. and Tichler, R. (2013) Wirtschaftskraft Erneuerbarer Energie in Österreich und Erneuerbare Energie in Zahlen. Blue Globe Report \#1/2013, Austrian Climate and Energy Fund, Vienna.

[21] Goers, S., Steinmüller, H., Schneider, F. and Zauner, A. (2017) Economic Growth and Employment Effects as a Result of the Upper Austrian Flood Protection Building Program. In: Hromadka, T., Ed., Flood Risk Management, IntechOpen, London, 79-92. https://doi.org/10.1016/j.energy.2018.07.057

[22] Moser, S., Mayrhofer, J., Schmidt, R.-R. and Tichler, R. (2018) Socioeconomic Cost-Benefit-Analysis of Seasonal Heat Storages in District Heating Systems with Industrial Waste Heat Integration. Energy, 160, 868-874.

https://doi.org/10.1016/j.energy.2018.07.057 
[23] Weishaar, S.E. (2018) Introducing Carbon Taxes at Member State Level. Issues and Barriers. WIFO Working Paper No. 556, Austrian Institute of Economic Research, Vienna.

[24] Statistik Austria (2017) Haushaltsenergie und Einkommen mit besonderem Fokus auf Energiearmut 2014. Vienna.

[25] Statistik Austria (2019) Mikrozensus Energieeinsatz der Haushalte 2013/2014 der Statistik Austria.

https://www.statistik.at/web_de/statistiken/energie_umwelt_innovation_mobilitaet/ energie_und_umwelt/energie/energieeinsatz_der_haushalte/index.html

[26] Moser, S., Leitner, K.H. and Steinmüller, H. (2014) F\&E-Fahrplan. Energieeffizienz in der energieintensiven Industrie. Austrian ClimateandEnergy Fund, Vienna.

[27] Zauner, A., Tichler, R., Baresch, M., Schwarz, M. and Reiter, G. (2017) Ökonomische Bewertung der wind2hydrogen Anlage. Energieinstitut an der Johannes Kepler Universität Linz, Linz.

[28] Steinmüller, H., Tichler, R., Kienberger, T., Gawlik, W., Lehner, M., Muggenhumer, G., Kriechbaum, L., Böckl, B., Winter, A., Biegger, P., Fazeni, K., Goers, S., Vopava, J., Ellersdorfer, M., Medved, A. and Mayrhofer, J. (2017) Smart Exergy Leoben: Exergetische Optimierung der Energieflüsse für eine smarte Industriestadt Leoben. Austrian Climate and Energy Fund, Vienna.

[29] Bundesministerium für Verkehr, Innovation und Technologie (2018) Move2Grid Umsetzung regionaler Elektromobilitätsversorgung durch hybride Kopplung. https://nachhaltigwirtschaften.at/de/sdz/projekte/move2grid.php

[30] Köppl, A., Kettner, C.,Kletzan-Slamanig, D., Schleicher, S., Schnitzer, H., Titz, M., Damm, A., Steininger, K., Wolkinger, B., Artner, H. and Karner, A. (2014) Energy Transition in Austria: Designing Mitigation Wedges. Energy \& Environment, 25, 281-304. https://doi.org/10.1260/0958-305X.25.2.281 